\title{
INOVASI PEMBELAJARAN DARING DALAM MERDEKA BELAJAR
}

\author{
Oleh \\ Sri Susanty \\ Sekolah Tinggi Pariwisata Mataram \\ Email: santy_010277@yahoo.com
}

\begin{abstract}
Abstrak
Keberadaan pandemi COVID-19 sangat berdampak terhadap berbagai sendi kehidupan manusia yang meliputi aspek kesehatan, ekonomi, sosial, budaya, juga terhadap sector pendidikan. Pembelajaran yang dilakukan secara daring ini menuntut perguruan tinggi untuk melakukan transformasi teknologi pembelajaran dalam waktu yang pendek. Penerapan pembelajaran daring ini menuntut kesiapan bagi kedua belah pihak, baik itu dari penyedia layanan pendidikan atau dari peserta didik sendiri. Faktanya tidak semua dosen berkesempatan mengikuti pelatihan e-learning yang diselenggarakan sebelumnya karena jumlah peserta yang mengikuti pelatihan terbatas. Oleh karena itu, berbagai inovasi pendidikan harus dilakukan dengan memastikan kegiatan belajarmengajar tetap dapat berjalan efektif meskipun dilakukan di rumah.Artikel ini bertujuan untuk membahas tentang inovasi pembelajaran dalan merdeka belajar. Penelitian ini merupakan jenis penelitian kualitatif dimana data diperoleh secara primer dan sekunder. Pengumpulan data lebih dominan melalui studi pustaka dan observasi yang dialkukan terhadap perilaku mahasiswa dan dosen yang melakukan proses pembelajaran pada masa pandemic ini. Untuk memastikan pembelajaran menjadi menyenangkan, penuh makna, membangkitkan kreativitas, daya kritis, dan mampu membuat mahasiswa mandiri tentu bukan perkara mudah. Kejelian dosen dalam membuat desain dan metode yang mampu memikat mahasiswa untuk terus bersemangat belajar menjadi hal yang patut diperhatikan. Kreatifitas mahasiswa juga dituntut dalam mengatasi perbagai persoalan seperti keterbatasan kuota dan signal. Model pembelajaran yang kolaboratif, inovatif dan eksperimental salah satu model pembelajaran dalam belajar merdeka adalah pembelajaran berbasis project atau project based learning. Project based learning atau pembelajaran berbasis proyek merupakan model pembelajaran yang berpusat pada peserta didik untuk melakukan suatu investigasi yang mendalam terhadap suatu topik. Peserta didik secara konstruktif melakukan pendalaman pembelajaran dengan pendekatan berbasis riset terhadap permasalahan dan pertanyaan yang berbobot, nyata, dan relevan. Adapun manajemen pembelajaran project based leaning di Masa Pandemi Covid yaitu: tetapkan manajemen waktu, persiapkan teknologi yang dibutuhkan, belajarlah dengan serius, dan jaga komunikasi dengan pengajar dan teman kelas.
\end{abstract}

Kata Kunci: Inovasi, Pembelajaran, Daring \& Merdeka Belajar

\section{PENDAHULUAN}

Organisasi Kesehatan Dunia (WHO: World Health Organization WHO) kini telah menetapkan virus Corona atau COVID-19 sebagai pandemi dunia yang telah menyebar ke lebih dari 120 negara di belahan dunia. Hal ini sejalan dengan batasan pendemi yang dikeluarkan oleh Kamus Besar Bahasa Indonesia (KBBI), bahwa pandemi adalah wabah yang berjangkit serempak di mana-mana atau meliputi geografi yang luas. Lebih lanjut, WHO sendiri menekankan bahwa pandemi merupakan situasi ketika populasi seluruh dunia terdapat kemungkinan terinfeksi dan berpotensi sebagian dari mereka jatuh sakit.

Sebagaimana wabah penyakit sebelumnya yang pernah menimpa masyarakat di berbagai belahan dunia, keberadaan pandemi COVID-19 sangat berdampak terhadap berbagai sendi kehidupan manusia yang meliputi aspek kesehatan, ekonomi, sosial, budaya, juga terhadap sector pendidikan. Menurut data Organisasi Pendidikan, Keilmuan, dan Kebudayaan PBB 
(UNESCO), setidaknya ada 290,5 juta siswa di seluruh dunia yang aktivitas belajarnya menjadi terganggu akibat sekolah yang ditutup. Di tingkat perguruan tinggi Amerika serikat, wabah virus corona juga menunjukkan intervensinya. Program pertukaran mahasiswa antarnegara juga dihentikan. Ritme dan budaya belajar juga mengalami perubahan. Untuk tetap menjaga imunitas tubuh dan terjangkit, pemerintah Indonesia mengeluarkan aturan protocol covid yang harus diimplementasikan seperti penggunaan masker, menjaga jarak, selalu mencuci tangan dengan sabun pada air yang mengalir, serta menghindari kerumuman massa.

Dalam rangka percepatan penanganan Covid-19, Menteri Kesehatan mengeluarkan peraturan Menteri Kesehatan No.9 Tahun 2020 tentang Pembatasan Sosial Berskala Besar (PSBB). Pembatasan tersebut meliputi peliburan sekolah dan tempat kerja, pembatasan kegiatan keagamaan, pembatasan kegiatan di tempat atau fasilitas umum, pembatasan kegiatan social budaya, pembatasan moda transportasi, dan pembatasan kegiatan lainnya khusus terkait aspek pertahanan dan keamanan. Protokol covid dan PSBB ini berpengaruh terhadap hak-hak pendidikan peserta didik di masa depan. Jika kondisi seperti ini terus meningkat, maka peserta didik di instansi penyelenggara pelayanan pendidikan, seperti sekolah disemua tingkatan, lembaga pendidikan non formal hingga perguruan tinggi akan mengalami dampak yang signifikan.

Indonesia sempat meliburkan seluruh aktivitas pendidikan, membuat pemerintah dan lembaga terkait harus menghadirkan alternatif proses pendidikan bagi peserta didik maupun mahasiswa yang tidak bisa melaksanakan proses pendidikan pada lembaga pendidikan. pemerintah mengumumkan Ujian Nasional (UN) di tahun ini resmi ditiadakan. Mulai dari tingkat Sekolah Dasar (SD) hingga setingkat Sekolah Menengah Atas (SMA). Pemerintah telah mengeluarkan himbauan terkait pendidikan yaitu untuk kegiatan belajar mengajar semua jenjang dilakukan di rumah peserta didik masing-masing dan para guru maupun pengajar dapat melakukan proses belajar mengajar melalui media daring (online). Himbauan tersebut disambut dengan pemberlakuan pembelajaran di rumah masing-masing di semua jenjang pendidikan dan menutup sementara sekolah dan perguruan tinggi dari aktivitas belajar mengajar. Iklim pembelajaran yang semula didominasi klasikal menjadi nonklasikal atau dengan pembelajaran jarak jauh

Inovasi pembelajaran merupakan solusi yang perlu didesain dan dilaksanakan oleh dosen dengan memaksimalkan media yang ada seperti media daring (online). Dosen dapat melakukan pembelajaran menggunakan metode e-learning yaitu pembelajaran memanfaatkan teknologi informasi dan komunikasi. Sistem pembelajaran dilaksanakan melalui perangkat komputer (PC) atau laptop yang terhubung dengan koneksi jaringan internet. Dosen dapat melakukan pembelajaran bersama diwaktu yang sama menggunakan grup di media sosial seperti Whatsapp (WA), telegram, aplikasi Zoom ataupun media sosial lainnya sebagai sarana pembelajaran sehingga siswa dapat dipastikan belajar di waktu bersamaan meskipun tidak berada dalam kelas namun bisa di rumah atau di tempat lain.

Dosen juga dapat memberikan tugas terukur namun tetap memastikan bahwa tiap hari pembelajaran terlaksana tahap demi tahap dari tugas tersebut. Banyak lagi inovasi lainnya yang bisa dilakukan oleh pendidik demi memastikan pembelajaran tetap berjalan dan peserta didik mendapatkan ilmu sesuai kurikulum yang telah disusun pemerintah. Pimpinan juga harus berinovasi dalam menjalankan fungsi supervisi atau pembinaan kepada tenaga pengajar untuk memastikan bahwa kegiatan belajar mengajar telah dilakukan oleh pendidik dan peserta didik meskipun menggunakan metode jarak jauh (daring).

Pembelajaran yang dilakukan secara daring ini menuntut perguruan tinggi untuk melakukan transformasi teknologi pembelajaran dalam waktu yang pendek. Perguruan tinggi dipaksa untuk melakukan 
revolusi proses pembelajaran melalui pemanfaatan teknologi pembelajaran daring. Pemanfaatan teknologi untuk pembelajaran daring telah dirintis sejak tahun 2000 lalu melalui berbagai platform antara lain GDLNINA, INHERENT, Jardiknas dan ID-REN. Kemudian pada 2014 Kemdikbud meluncurkan platform SPADA. Namun saat itu belum banyak kampus yang berkeinginan untuk menggunakannya. Perubahan secara significant terjadi sejak pandemic. Kini hampir seluruh kampus melakukan pembelajaran daring pada masa pandemi saat ini. Kementerian Pendidikan dan Kebudayaan melalui Direktorat Jenderal Pendidikan Tinggi telah menyediakan platform pembelajaran daring yang dapat digunakan secara bersama lintas kampus melalui SPADA. Platform ini juga bisa digunakan oleh kampus-kampus yang belum memiliki Learning Management System (LMS) untuk pelaksanaan proses pembelajaran daring. Saat ini di dalam SPADA terdapat 244 perguruan tinggi yang berbagi modul perkuliahan dan lebih dari 3.000 konten yang dapat digunakan dalam pembelajaran daring yang dapat diakses secara gratis. (http://dikti.go.id/kabar/optimalisasi-

pembelajaran-daring-dalam-merdeka-belajar/)

Dalam masa pandemi ini, pembelajaran tidak hanya dapat dilakukan secara daring namun banyak pilihan model pembelajaran yang dapat dilakukan oleh mahasiswa. Hal ini selaras dengan kebijakan Merdeka Belajar yang dicanangkan Menteri Pendidikan dan Kebudayaan. Esensinya pembelajaran tidak hanya terbatas pada ruang kelas, perpustakaan dan laboratorium semata. Mahasiswa dapat melakukan metode pembelajaran lainnya misalnya proyek mandiri, penelitian bersama dosen atau peneliti, atau pembelajaran dengan terlibat secara langsung pada program-program kemanusiaan. Kampus juga juga diharapkan memberikan kebebasan mahasiswa dalam berkreasi dan melakukan inovasi-inovasi baru dalam pembelajaran. Merdeka belajar lebih berfokus pada bagaimana mahasiswa memperoleh nilai tambah baik dari sisi keilmuan maupun pengembangan kompetensi yang dimiliki. (http://dikti.go.id/kabar/optimalisasipembelajaran-daring-dalam-merdeka-belajar/)

Penerapan pembelajaran daring ini menuntut kesiapan bagi kedua belah pihak, baik itu dari penyedia layanan pendidikan atau dari peserta didik sendiri. Bagaimanapun juga, pembelajaran secara daring dan jarak jauh membutuhkan bantuan teknologi yang mumpuni dan dapat diakses dengan mudah. Selain itu, para mahasiswa juga mesti siap beradaptasi dengan perubahan pembelajaran yang diatur oleh kampus. Remote learning dapat dipandang lebih bebas dan fleksibel diakses dari rumah.

Kemudian, seiring dengan pembelajaran jarak jauh ini berlangsung, muncul berbagai kendala. Di Perguruan Tinggi, dosen harus memastikan kegiatan belajar-mengajar tetap berjalan meskipun mahasiswa berada dirumah. Mahasiswa dituntut untuk melakukan pembelajaran secara mandiri. Mahasiswa "dipaksa" belajar dari rumah karena pembelajaran tatap muka ditiadakan untuk mencegah penularan covid-19. Dengan adanya wabah ini mampu mempercepat proses perubahan iklim pembelajaran termasuk di universitas dan semua pihak dipaksa beradaptasi dengan cepat termasuk metode dan cara perkuliahan maupun praktikum.. Namun ternyata kondisi pandemic membuat percepatan semua pihak untuk mengenal sistem perkuliahan daring yang sebelumnya cukup asing bagi semua pihak. Termasuk presensi digital yang belum diterapkan maksimal namun sejak terjadi BDR ini menjadi hal yang biasa dan mesti dilakukan sebagai pengganti Daftar Hadir Kuliah manual (DHK). Kini pembelajaran yang biasanya on-site menjadi online. Biasanya tatap muka menjadi tatap layar. Semua interaksi menjadi serba digital. Jaringan internet dan tentunya keberadaan kuota menjadi tulang punggung semua proses tersebut. Kondisi Work from Home dan Study from Home memaksa semua pihak untuk berupaya memaksimalkan proses pembelajaran. Belum ada kepastian kapan pandemic ini akan berakhir. Maka semua pihak harus memutar otak mancari cara menggunakan alternatif proses kegiatan belajar-mengajar 
yang dirasa terkesan "mendadak" serba digital. Siap tidak siap harus dihadapi. Waluapun di dunia pendidikan semestinya hal ini bukan hal baru, mungkin hanya saja kita yang terlambat mengetahui dan mengaplikasikan.

Pendidik meyakini bahwa mahasiswa milenial tak asing dengan kehidupan serba digital bahkan sejak lahir sudah terpapar dengan teknologi digital ini, ternyata peserta didik sangat mudah beradaptasi. Bahkan dengan sendirinya mereka mampu menyelesaikan segala tugas dari gawai cerdas digenggaman. Justru tantangan ada para pendidik yang mesti segera beradaptasi dengan era digital. Padahal tidak semua dosen terbiasa mengajar melalui online. Apalagi guru dan dosen masih banyak belum mahir mengajar dengan menggunakan teknologi internet atau media sosial terutama di berbagai daerah. Faktanya tidak semua dosen berkesempatan mengikuti pelatihan e-learning yang diselenggarakan sebelumnya karena jumlah peserta yang mengikuti pelatihan terbatas. Oleh karena itu, berbagai inovasi pendidikan harus dilakukan dengan memastikan kegiatan belajarmengajar tetap dapat berjalan efektif meskipun dilakukan di rumah.

Kemajuan teknologi seperti mesin pencari google tidak bisa menggantikan peran guru dan dosen. Bagaimanapun peran guru dan dosen sesungguhnya tidak bisa digantikan dangan teknologi. Karena guru dan dosen bukan sekedar sumber ilmu pengetahuan, melainkan mesti menjadi contoh dan teladan yang mentransfer adab dan tata nilai. Keberadaan fisik seorang guru dan dosen tetap dibutuhkan oleh peserta didik dalam proses belajar mengajar karena fungsinya tidak hanya menyampaikan materi dan transfer ilmu namun mendidik karakter serta mengajarkan bagaimana memaknai dan menjalani hidup dengan lebih baik. Hal yang perlu direfleksikan, bahwa hal penting dalam hidup seperti tanggung jawab, kedisiplinan, rasa empati kepada orang lain, jujur, kerja keras, saling menghormati, mencintai sesama manusia, kesederhanaan, keikhlasan, dan lain-lain tidak bisa ditemukan bahkan dalam gawai yang smart sekalipun. Hal itu hanya didapat dari keteladanan dan pembiasaan karakter. Itulah peran sejati guru dan dosen yang digugu dan ditiru yang tak mampu di gantikan oleh teknologi manapun.

Era digital ini justru sangat membutuhkan peran guru dan dosen dalam memfilter informasi kepada para peserta didik. Oleh karena itu, menjadi tantangan pendidik yang dapat menyesuaikan diri dengan perkembangan zaman terutama era digital ini membuka inovasi dalam mengajar. Pendidik mestinya tidak enggan dan segan untuk mencoba platform digital, melalui platform digital pembagian tugas menjadi semakin mudah dan juga menjadwalkan proses pembelajaran lebih mudah dengan adanya learning management system

Artikel ini bertujuan untuk membahas tentang inovasi pembelajaran dalan merdeka belajar. Penelitian ini merupakan jenis penelitian kualitatif dimana data diperoleh secara primer dan sekunder. Pengumpulan data lebih dominan melalui studi pustaka dan observasi yang dialkukan terhadap perilaku mahasiswa dan dosen yang melakukan proses pembelajaran pada masa pandemic ini.

\section{LANDASAN TEORI}

Menurut Kamus Besar Bahasa Indonesia (KBBI), kata "inovasi" berarti penemuan baru yang berbeda dari yang sudah ada atau yang sudah dikenal sebelumnya. Inovasi memiliki kaitan yang cukup erat dengan teknologi, ide, dan pengetahuan. Teknologi memang pada dasarnya diciptakan untuk memudahkan hidup manusia mulai dari segi komunikasi hingga pendidikan.

Kolaborasi antara inovasi dan teknologi dapat sangat membantu kamu untuk belajar lebih banyak dan lebih baik tentang banyak hal, misalnya dalam pembelajaran diperkuliahan. Dengan bantuan teknologi, kamu bisa bise beajar lebih mudah dan efektif.

Luthra \& Mackenzi (2020) menyebut ada empat cara COVID-19 mengubah cara kita mendidik generasi masa depan. Pertama, bahwa proses pendidikan di seluruh dunia semakin saling terhubung. Kedua, pendefinisian ulang peran pendidik. Ketiga, mengajarkan 
pentingnya keterampilan hidup di masa yang akan datang. Dan, keempat, membuka lebih luas peran teknologi dalam menunjang pendidikan. Selain itu, Tam dan El Azar (2020) menyatakan pandemi virus corona menyebabkan tiga perubahan mendasar di dalam pendidikan global. Pertama, mengubah cara jutaan orang dididik. Kedua, solusi baru untuk pendidikan yang dapat membawa inovasi yang sangat dibutuhkan. Ketiga, adanya kesenjangan digital menyebabkan pergeseran baru dalam pendekatan pendidikan dan dapat memperluas kesenjangan.

UNICEF, WHO dan IFRC dalam COVID-19 Prevention and Control in Schools (Maret, 2020) menyebut bahwa ketika situasi persebaran virus semakin cepat maka sekolah harus ditutup dan proses pendidikan harus tetap berjalan melalui kegiatan pembelajaran online dengan menggunakan berbagai media. Data UNESCO (2020) menyebut 1,5 miliar siswa dan 63 juta guru di tingkatan sekolah dasar hingga menengah di 191 negara yang terdampak pandemi Covid-19, sesuatu yang tidak pernah terjadi sebelumnya. Dunia pendidikan kemudian, 'terpaksa' putar haluan untuk mengubah cara belajar berbasis perjumpaan tatap muka menjadi pembelajaran daring. Transformasi digital secara terpaksa ini adalah cara yang paling aman untuk memutus penyebaran wabah akibat virus corona. Sebab, hak para siswa untuk mendapatkan pendidikan tetap menjadi prioritas tanpa mengabaikan kesehatan dan keselamatan jiwa.

Negara-negara di dunia, mengutip Zhong (2020) dalam artikelnya di nytimes.com "The Coronavirus Exposes Education's Digital Divide", menghadapi wabah yang menyebabkan sekolah-sekolah harus menyelenggarakan pembelajaran secara daring. Di China banyak orangtua yang tidak mampu membeli perangkat digital untuk mendukung pembelajaran daring juga adanya keterbatasan sinyal di beberapa wilayah perdesaan. Biaya internet juga sangat mahal di luar kota besar. Yang menarik China memiliki mantra sakti: stop classes but don't stop learning.

Dalam situasi normal, di mana tidak ada situasi krisis, mengupayakan pembelajaran daring bukanlah hal mudah. Ada beberapa prasyarat yang harus dipenuhi. Selain itu, pembelajaran daring membutuhkan siswa yang telah dewasa yang secara mandiri menyesuaikan kebutuhan pembelajaran yang ditujunya.

Hoskins (2013) menyebut tidak mudahnya melakukan pembelajaran jarak jauh di kalangan mahasiswa. Padahal pembelajaran ini lebih mudah dilakukan pada mahasiswa yang sudah dewasa. Selain itu pembelajaran ini harus didukung oleh desain kelas dan metode penyampaian yang tepat sehingga pembelajaran daring dapat mendorong mahasiswa untuk merefleksikan kepercayaan mereka; menyediakan lingkungan yang aman untuk mendiskusikan berbagai perspektif; membimbing mereka untuk mengeksplorasi, memvalidasi, dan memperluas pandangan baru; dan mendukung mereka mengembangkan peran baru.

Selain itu, akses menjadi kata kunci bagi optimalnya pembelajaran daring. Lembani, dkk (2019) menyebut open distance learning meningkatkan peluang bagi akses ke pendididikan karena tersedianya materi daring. Namun, kondisi tersebut sangat dipengaruhi oleh beragam variabel seperti umur, akses terhadap komputer dan internet, maupun kesenjangan digital. Memfasilitasi akses yang memadai misalnya, menjadi salah satu hal yang sangat mendasar dalam mendukung kelancaran open distance learning.

Selama masa pandemic COVID-19 pembelajaran dirumah atau online menjadi solusi melanjutkan sisa semester. Pembelajaran online didefinisikan sebagai pengalaman transfer pengetahuan menggunakan video, audio, gambar, komunikasi teks, perangkat lunak (Basilaia \& Kvavadze, 2020) dan dengan dukungan jaringan internet (Zhu \& Liu, 2020). Ini merupakan modifikasi transfer pengetahuan melalui forum website (Basilaia \& Kvavadze, 2020) dan tren teknologi digital sebagai ciri khas dari revolusi industry 4.0 untuk menunjang pembelajaran selama masa pandemic COVID-19. Integrasi teknologi dan ragam inovasi ciri dari pembelajaran online (Banggur et al., 2018). Selain itu, yang 
terpenting adalah kesiapan pendidik dan peserta didik untuk berintereaksi secara online. Infrastruktur yang mendukung pembelajaran online secara gratis melalui berbagai ruang diskusi seperti Google Classroom, Whatsapp, Kelas Cerdas, Zenius, Quipper dan Microsoft (Abidah et al., 2020). Fitur Whatsapp mencakup Whatsapp Group yang dapat digunakan untuk mengirim pesan teks, gambar, Jurnal Teknologi Pendidikan Vol. 22, No. 1, April 202068 video dan file dalam berbagai format kepada semua anggota (Kusuma \& Hamidah, 2020).

Google Clasroom juga memungkinkan pendidik dan guru mengembangkan pembelajaran kreatif. Diskusi dan transfer pengetahuan secara face-to-face layaknya bertemu melalui beragam platform video teleconference yang banyak tersedia gratis seperti Zoom dan Google Meet. Platform tersebut menjadikan pendidik dan peserta didik untuk bertemu dan berinteraksi secara virtual dengan fasilitas pesan instan dan kegiatan presentasi (Wiranda \& Adri, 2019). Berbagai layanan tersebut dapat dimanfaatkan sebagai penunjang transfer pengetahuan hingga diskusi terkait konten pembelajaran. Ini juga dilakukan dengan memanfaatkan segala sumber daya local secara nasional seperti saluran televisi untuk edukasi (Zhou et al., 2020). Di Indonesia, televisi pada saluran TVRI digunakan untuk menyiarkan konten edukasi secara nasional. Konten yang disiarkan digolongkan berdasarkan jenjang pendidikan yang sesuai dengan kurikulum di Indonesia. Variasi platform dan seumber daya yang tersedia membantu menunjang proses pembelajaran selama pandemic COVID-19. Aktifitas pembelajaran yang dapat dilakukan mulai dari diskusi, presentasi hingga pemberian tugas. Ini selaras dengan penelitian Firman dan Rahayu (2020) bahwa pembelajaran online melatih kemandirian belajar. Ini akan membutuhkan keterlibatan peserta didik yang lebih besar untuk meningkatkan perilaku belajar observasional. Perilaku tersebut dapat dilakukan dengan membaca, memaknai postingan diskusi dan mendiskusikan video atau konten pembelajaran (Zayapragassarazan,
2020). Ini akan membiasakan peserta didik untuk mengumpulkan dan mengelola informasi terkait tugas yang diberikan tanpa batasan ruang dan waktu. Hal ini dikarenakan pembelajaran online memungkinkan akses informasi dan pengetahuan dirumah dan dimanapun yang disesuaikan dengan kenyamanan peserta didik. Belajar online menuntut peran pendidik mengevaluasi efektivitas dan disesuaikan dengan kebutuhan belajar. Ini penting dilakukan untuk tetap memenuhi aspek pembelajaran seperti proses pengetahuan, moral, keterampilan, kecerdasan dan estetika (Dai \& Lin, 2020; Zhu \& Liu, 2020). Mengingat bahwa perubahan ke pembelajaran online secara tidak langsung berpengaruh pada daya serap peserta didik (Dewi, 2020). Penting untuk diperhatikan yakni komunikasi orang tua dan pendidik untuk mewujudkan kemandirian belajar peserta didik selama masa pandemic COVID-19. Ragam manfaat yang diperoleh, tentu memiliki kendala yang dirasakan pendidik maupun peserta didik dalam pembelajaran online. Kendala yang dihadapi yakni kondisi wilayah di Indonesia yang beragam menyebabkan tidak semua wilayah terjangkau oleh layanan internet dan sebaran jaringan internet yang lamban sewaktuwaktu (Khasanah et al., 2020). Ini juga memungkinkan penggunaan internet yang tinggi berpengaruh pada kesehatan peserta didik. Kendala lain yang ditemukan yakni kemampuan orang tua untuk memberikan fasilitas pendidikan online (Obiakor \& Adeniran, 2020) seperti penggunaan jaringan internet yang membutuhkan biaya (Jones \& Sharma, 2019; Purwanto et al., 2020). Luh Devi Herliandry dkk, Pembelajaran pada Masa Pandemi Covid 1969 Permasalahan tersebut tentu harus tetap di evaluasi guna memperoleh pembelajaran yang lebih baik. Kuncinya adalah untuk melakukan pembelajaran online sesaui dengan kondisi setempat (Zhang et al., 2020). Hal terpenting untuk menciptakan kemandirian dan keterampilan belajar peserta didik di tengah pandemic COVID-19. 


\section{HASIL DAN PEMBAHASAN}

\section{Inovasi Pembelajaran Daring Dalam Merdeka Belajar}

Di Indonesia pembelajaran daring/jarak jauh diatur melalui Surat Edaran Kemdikbud No 4 Tahun 2020 mengenai Pelaksanaan Pendidikan Dalam Masa Darurat Coronavirus Disease (Covid-19). Dalam surat edaran ini, pemerintah mengeluarkan kebijakan terkait pembelajaran daring.

1. Pembelajaran daring/jarak jauh untuk memberi pengalaman belajar yang bermakna, tanpa terbebani tuntutan menuntaskan seluruh capaian kurikulum untuk kenaikan kelas maupun kelulusan.

2. Difokuskan pada pendidikan kecakapan hidup, antara lain mengenai pandemi Covid-19.

3. Aktivitas dan tugas pembelajaran dapat bervariasi antar siswa, sesuai minat dan kondisi masing-masing, termasuk mempertimbangkan kesenjangan akses/fasilitas belajar di rumah.

Implementasi pembelajaran sebagaimana diamanatkan oleh pemerintah ini sangat tergantung kepada dukungan dari semua kalangan baik dari pemerintah, kesiapan infrastruktur pendukung, serta kreativitas mahasiswa dan dosen. Pemerintah berperan dalam membuat kebijakan berkaitan dengan system pembelajaran daring, perangkat digital, koneksi internet yang lancar, dan kuota murah yang bisa dijangkau oleh seluruh lapingan masyarakat baik yang berada di kota maupun di daerah perdesaan. Pembelajaran daring sangat membutuhkan infrastruktur pembelajaran berbasis teknologi yang mudah diakses oleh dosen dan mahasiswa. Perangkat system pembelajaran digital yang telah disediakan oleh pemerintah akan sangat membantu dalam memudahkan proses pembelajaran. Kampus yang telah lama menerapkan system pembelajaran digital sangat adaptif dalam mengadopsi system pembelajaran daring. Untuk memudahkan mahasiswa memahami materi yang diajarkan, kreativitas dosen sangat dituntut. Beragam perangkat daring (zoom, google meet, webex, dsb) dapat optimal dilakukan melalui penyajian materi yang menarik. Penggunaan perangkat daring juga meski dipikirkan disesuaikan dengan kemampuan sosial ekonomi mahasiswa dalam menyediakan kuota dan keterjangkauan signal.

Untuk memastikan pembelajaran menjadi menyenangkan, penuh makna, membangkitkan kreativitas, daya kritis, dan mampu membuat mahasiswa mandiri tentu bukan perkara mudah. Kejelian dosen dalam membuat desain dan metode yang mampu memikat mahasiswa untuk terus bersemangat belajar menjadi hal yang patut diperhatikan. Kreatifitas mahasiswa juga dituntut dalam mengatasi perbagai persoalan seperti keterbatasan kuaota dan signal.

Project Based Learning, inovasi model Pembelajaran Merdeka Belajar

Pada masa pandemic sekarang diperlukan model pembelajaran yang kolaboratif, inovatif dan eksperimental. Salah satu model pembelajaran dalam belajar merdeka adalah pembelajaran berbasis project atau project based learning. Grant (2002) mendefinisikan project based learning atau pembelajaran berbasis proyek merupakan model pembelajaran yang berpusat pada peserta didik untuk melakukan suatu investigasi yang mendalam terhadap suatu topik. Peserta didik secara konstruktif melakukan pendalaman pembelajaran dengan pendekatan berbasis riset terhadap permasalahan dan pertanyaan yang berbobot, nyata, dan relevan. Sedangkan Made Wena (dalam Lestari, 2015: 14) menyatakan bahwa model project based learning adalah model pembelajaran yang memberikan kesempatan kepada pendidik untuk mengelola pembelajaran di kelas dengan melibatkan kerja proyek. Kerja proyek merupakan suatu bentuk kerja yang memuat tugas-tugas kompleks berdasarkan kepada pertanyaan dan permasalahan yang sangat menantang dan menuntun peserta didik untuk merancang, memecahkan masalah, membuat keputusan, melakukan kegiatan investigasi, serta memberikan kesempatan peserta didik untuk bekerja secara mandir

Menurut Rais dalam Lestari (2015) langkah-langkah model pembelajaran project 
based learning adalah sebagai berikut:

1. Membuka perkuliahan dengan suatu pertanyaan menantang (driving question) yang dapat memberi penugasan pada peserta didik untuk melakukan suatu aktivitas. Topik yang diambil hendaknya sesuai dengan realita dunia nyata dan dimulai dengan sebuah investigasi mendalam.

2. Merencanakan proyek (design a plan for the project). Perencanaan dilakukan secara kolaboratif antara dosen dan mahasiswa. Dengan demikian peserta didik diharapakan akan merasa memiliki atas proyek tersebut. Perencanaan berisi tentang aturan main, pemilihan aktivitas yang dapat mendukung dalam menjawab pertanyaan esensial dengan mengintegrasikan berbagai subjek yang mendukung, serta menginformasikan alat dan bahan yang dapat dimanfaatkan untuk menyelesaikan proyek.

3. Menyusun jadwal aktivitas (create a schedule). Pendidik dan peserta didik secara kolaboratif menyusun jadwal aktivitas dalam menyelesaikan proyek. Waktu penyelesaian proyek harus jelas, dan mahasiswa diberi arahan untuk mengelola waktu yang ada. Biarkan peserta didik mencoba menggali sesuatu yang baru, akan tetapi pendidik juga harus tetap mengingatkan apabila aktivitas peserta didik melenceng dari tujuan proyek. Proyek yang dilakukan oleh peserta didik adalah proyek yang membutuhkan waktu yang lama dalam pengerjaannya, sehingga pendidik meminta peserta didik untuk menyelesaikan proyeknya secara berkelompok di luar jam sekolah.

4. Mengawasi jalannya proyek (monitor the students and the progress of the project). Pendidik bertanggungjawab untuk melakukan monitor terhadap aktivitas peserta didik selama menyelesaikan proyek. Monitoring dilakukan dengan cara memfasilitasi peserta didik pada setiap proses. Dengan kata lain, pendidik berperan sebagai mentor bagi aktivitas peserta didik. Pendidik mengajarkan kepada peserta didik bagaimana bekerja dalam sebuah kelompok. Setiap peserta didik dapat memilih perannya masing masing dengan tidak mengesampingkan kepentingan kelompok.

5. Penilaian terhadap produk yang dihasilkan (assess the outcome). Penilaian dilakukan untuk membantu pendidik dalam mengukur ketercapaian standar, berperan dalam mengevaluasi kemajuan masing masing peserta didik, memberi umpan balik tentang tingkat pemahaman yang sudah dicapai oleh peserta didik, serta membantu pendidik dalam menyusun strategi pembelajaran berikutnya. Penilaian produk dilakukan saat masingmasing kelompok mempresentasikan produknya di depan kelompok lain secara bergantian.

6. Evaluasi (evaluate the experience). Pada akhir proses pembelajaran, pendidik dan peserta didik melakukan refleksi terhadap aktivitas dan hasil proyek yang sudah dijalankan. Proses refleksi dilakukan baik secara individu maupun kelompok. Pada tahap ini, peserta didik diminta untuk mengungkapkan perasaan dan pengalamannya selama menyelesaikan proyek

Diskripsi pengalaman belajar dan kompetensi yang diperoleh mahasiswa dapat diperoleh dengan menghubungkan alur/tahapan pembelajaran (learning path) dari model pembelajaran project based learning yaitu 4C: creative (berpikir kreatif), collaborative (bekerjasama), communication (berkomunikasi), critical (berpikir kritis), dan 1Q yaitu taqwa dengan pendekatan saintifik yaitu 5M: Mengamati, Mengasosiasi, Mencoba, Mendiskusikan, dan Mengkomunikasikan.

Pengalaman belajar peserta didik selama pelaksanaan model pembelajaran project based learning antara lain peserta didik diajak untuk peduli terhadap masalah-masalah di lingkungan sekitar dalam kehidupan mereka sehari hari, berlatih untuk peka pada lingkungan, belajar mencari pertanyaan esensial, peserta didik berlatih berpikir logis, kritis, dan detil, berfikir tentang detil pekerjaan yang harus dilakukan, 
berfikir asosiatif yakni menghubungkan satu aspek pekerjaan dengan pekerjaan lainnya, berpikir tentang urutan waktu, dan belajar membagi tugas.

https://sibatik.kemdikbud.go.id/inovatif/ assets/file_upload/pengantar/pdf/pengantar_5. pdf

Adapun manajemen pembelajaran project based leaning di Masa Pandemi Covid yaitu:

1. Tetapkan manajemen waktu

Manajemen waktu sangat menentukan keberhasilan mahasiswa dalam mengerjakan tugasnya. Tugas yang diberikan kepada mahasiswa harus terukur dalam penyelesaiannya dan ada batasan waktu baik dalam proses penugasan maupun saat penyelesaian tugas. Fleksibilitas waktu belajar mandiri bisa diatur dan disepakati bersama antara mahasiswa dan dosen sehingga mahasiswa dapat mengatur waktu belajar mereka secara teratur. Mahasiswa yang belum terbiasa belajar mandiri, umumnya mengerjakan tugas-tugas pada menit-menit terakhir tenggat waktu yang ditetapkan. Oleh sebab itu, membiasakan diri untuk belajar dan mengerjakan tugas di awal waktu adalah keterampilan yang mesti ditanamkan kepada mahasiswa yang melakukan pembelajaran jarak jauh.

2. Persiapkan teknologi yang dibutuhkan

Para mahasiswa harus mengetahui peralatan-peralatan apa saja yang dibutuhkan untuk melakukan pembelajaran jarak jauh. Tidak semua sekolah sudah menyediakan layanan belajar daring yang memadai, oleh karenanya beberapa platform belajar daring dapat menjadi alternatif. Demikian juga perkakas teknologi seperti komputer, gawai pintar, atau laptop menjadi penting, dan terutama juga jaringan internet yang baik.

3. Belajarlah dengan serius

Kesalahan yang sering dilakukan mahasiswa adalah tidak fokus ketika melakukan remote learning. Selama melakukan pembelajaran di internet, terdapat banyak sekali distraksi yang mengganggu proses pembelajaran. Godaan untuk menonton video, mengakses media sosial, hingga membaca-baca konten berita secara impulsif seringkali dilakukan tanpa rencana sebelumnya. Oleh sebab itu, penting bagi siswa untuk berusaha fokus dan konsisten selama waktu belajar yang ditetapkan. Hindari segala macam distraksi yang berpotensi mengganggu proses belajar. Jika memungkinkan, tetapkan ruang khusus untuk belajar dan menjauhkan diri dari gangguan anggota keluarga yang lain.

4. Jaga komunikasi dengan pengajar dan teman kelas

Bagi yang belum terbiasa melakukan remote learning, ia harus menyesuaikan diri untuk terus visible dan berkomunikasi tanggap dengan pengajar atau teman kelas lain. Jika dibutuhkan, perlu juga diadakan grup khusus untuk membahas tugas yang dibebankan pengajar. Kendati tidak harus dilakukan dengan tatap muka, komunikasi mesti terjalin dengan baik untuk menghindari kesalah pahaman. Gunakan momen-momen semacam ini untuk mengasah keterampilan komunikasi daring yang dilakukan. Jika memang belum yakin dengan hasil tugas yang dikerjakan, mahasiswa dengan segera menghubungi dosen. Lakukan sesegera mungkin untuk menunjukkan komitmen bahwa kita serius untuk belajar. Kendati banyak mahasiswa merasa kesulitan melakukan remote learning, jika sudah terbiasa, hal ini malah memberi kebebasan dan fleksibilitas tersendiri, yang tidak ditemui pada kegiatan belajar mengajar di ruang kelas. Di tengah penyebaran wabah Covid-19, pembelajaran daring semacam ini justru dapat menjadi alternatif jitu sebagai ganti pertemuan kelas atau pembelajaran tatap muka.

\section{PENUTUP \\ Kesimpulan}

Masa pandemic ini memberikan tantangan bagi dunia pendidikan. Civitas akademika ituntut untuk adaptif dan kreatif dalam menciptakan atmosfer pembelajaran yang sesuai dengan perubahan jaman dan kondisi social ekonomi masyarakat. Pembelajaran daring merupakan salah satu alternative model pembelajaran yang memenuhi kriteria protocol covid-19. Keiatan belajar belajar daring akan menjadi lebih menarik dan peserta didik akan lebih kreatif 
jika pendidik juga kreatif dalam kegiatan mengajar. Pembelajaran daring menuntut adanya kesiapan teknologi dan SDM yang mumpuni. Teknologi diciptakan untuk melengkapi dan membantu manusia dalam mengerjakan tugas dan tanggung jawabnya, namun bukan untuk menggantikan perannya secara keseluruhan apalagi dosen sang pendidik generasi yang berperan dalam pengajaran dan pendidikan.

\section{Saran}

Di masa pandemic ini, kreatifitas dosen dan mahasiswa sangat diharapkan. Dalam proses pembelajaran daring, pembelajaran berbasis proyek (project based learning) menjadi salah satu referensi dalam inovasi pembelajaran. Model pembelajaran inovatif ini berguna untuk menghasilkan kualitas belajar mahasiswa

\section{DAFTAR PUSTAKA}

[1] Luh Devi Herliandry*1 , Nurhasanah2 , Maria Enjelina Suban 3 , Heru Kuswanto. 65 Pembelajaran Pada Masa Pandemi Covid-19 Jurnal Teknologi Pendidikan http://journal.unj.ac.id/unj/index.php/jtp Vol. 22, No. 1, April 2020

[2] Barbara J. Hoskins.2013.Is Distance Learning Transformational?.The Journal of Continuing Higher Education,61:1,6263,DOI: 10.1080/07377363.2013.759488.

[3] BPS. Potret Pendidikan Statistik Pendidikan Indonesia 2019. Jakarta: Badan Pusat

Statistik.https://www.bps.go.id/publication /2019/11/29/1deb588ef5fdbfba3343bb51/p otret-pendidikan-statistik-pendidikanindonesia-2019.html.

[4] Kementerian Pendidikan dan Kebudayaan. Surat Edaran Kemdikbud No 4 Tahun 2020 mengenai Pelaksanaan Pendidikan Dalam Masa Darurat Coronavirus Disease (Covid19). Jakarta: Kemendikbud. Sumber: https://www.kemdikbud.go.id/main/blog/2 020/03/mendikbud-terbitkan-se-tentangpelaksanaan-pendidikan-dalam-masadarurat-covid19.

[5] Luthra, Poornima \& Mackenzie, Sandy. 2020. 4 Ways Covid-19 Education Future
Generations. Sumber: https://www.weforum.org/agenda/2020/03/ 4-ways-covid-19-education-futuregenerations/.

[6] Reuben Lembani, Ashley Gunter, Markus Breines \& Mwazvita Tapiwa Beatrice Dalu. 2020.The same course, different access: the digital divide between urban and rural distance education students in South Africa.Journal of Geography in Higher Education,44:1,70-84,DOI: 10.1080/03098265.2019.1694876.

[7] Tam, Gloria \& El-Azar, Diana. 2020. 3 ways the coronavirus pandemic could reshape education. Sumber: https://www.weforum.org/agenda/2020/03/ 3-ways-coronavirus-is-reshapingeducation-and-what-changes-might-behere-to-stay/.

[8] UNICEF, IRC, \& WHO. 2020. Key Messages and Actions for COVID-19 Prevention and Control in Schools. Sumber: https://www.who.int/docs/defaultsource/coronaviruse/key-messages-andactions-for-covid-19-prevention-andcontrol-in-schools-march2020.pdf?sfvrsn=baf81d52_4. 